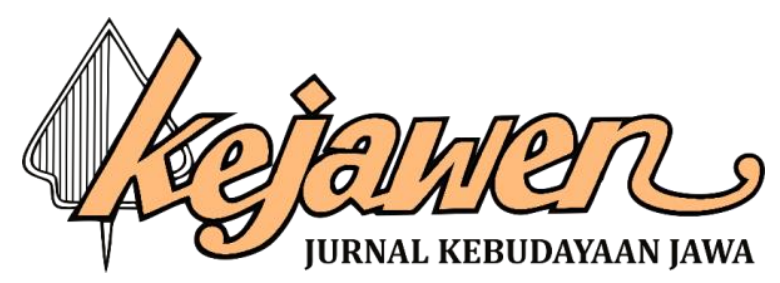

\title{
MAKNA TEKS KYAI PRELLAMBANG DALAM NASKAH KEMPALAN DONGENG: KAJIAN SEMIOTIKA
}

\author{
Galang Prastowo \\ Prodi Pendidikan Bahasa Jawa UNY \\ galang.prastowo@uny.ac.id
}

\begin{abstract}
Abstrak
Penelitian ini bertujuan untuk mencari makna yang terkandung dalam teks Kyai Prelambang dalam naskah Kempalan Dongeng dengan menggunakan analisis semiotika Riffatere. Metode penelitian yang digunakan dalam penelitian ini adalah metode analisis konten. Dimulai dengan pembacaan heuristik dan hermeneutik teks. Selanjutnya pencarian matriks dalam teks Kyai Prêlambang adalah pendidikan. Matriks tersebut ditransformasikan menjadi model perumpamaan yang berisi kebaikan, keburukan, usaha, dan imbalan atau balasan. Berdasarkan model, ditransformasikan lagi menjadi bentuk-bentuk varian. Varian dari teks Kyai Prêlambang adalah tindakan buruk, pertolongan Gusti Allah, balasan tindakan buruk, pertolongan manusia, perbuatan baik, perbuatan baik, balasan perbuatan baik, dan bakti kepada orang tua. Terakhir adalah mencari hipogram. Terdapat dua macam hipogram yaitu hipogram potensial dan hipogram aktual. Berdasar pencarian hipogram potensial, pertama teks Kyai Prêlambang berhubungan dengan kondisi sosial abad 18. Kedua, berhubungan dengan Islam: kekuasaan dari Allah dan ajaran dari kyai. Ketiga, berhubungan dengan kekuasaan raja di Yogyakarta dan Belanda. Hipogram aktual yang pertama yaitu naskah sebelum teks Kyai Prêlambang yang masih dalam satu naskah Kempalan Dongeng: Kisah Raden Mukjijat, Istrijat, dan Keramat. Kedua, Sastra Gending karya Sultan Agung.
\end{abstract}

Kata kunci: Teks Kyai Prelambang, semiotika, matriks, model, varian, hipogram

\section{THE MEANING OF KYAI PRELAMBANG TEXT IN KEMPALAN DONGENG'S SCRIPTURE: SEMIOTIC APPROACH}

\begin{abstract}
The following research is proposed to denote meaning in Kyai Prelambang text in KempalanDongeng Scripture by using Riffatere semiotics. The research method used in this research is the content analysis method. The analysis began with heuristic and hermeneutics' text. Soon, the matrix finding in Kyai Prelembangis about lessons. The metric is transferred into a parable model containing good deeds, bad deeds, effort and reward, and reprisal. Based on the model, the research will be transformed into another variant. The first text variant of Kyai Prelambang is bad deeds, God's assistance, reprisal, human kindness, good deeds, reward, and your devotion to your parents. And The last step is about finding hypogram. There are two hypograms. Those are potential hypogram and actual hypogram. Referring to the potential hypogram, the first text of Kyai Prelambang connected with the 18th-century social condition. The second text is related to the power of the emperor in Dutch and Yogyakarta. The first Actual Hipogram is scriptures preceding Kyai Prelambang text which exists as part of Kempalandongeng; Kisah Raden Mukjijat, Istrijat, dan Keramat. The second parts is Sastra Gending written by Sultan Agung.
\end{abstract}

Keywords: Kyai prelambang's text, semiotic, metrics, variant, hypogram 


\section{PENDAHULUAN}

Karya-karya sastra Indonesia terdiri atas karya sastra lisan dan karya sastra tulis. Karya sastra tulis terdiri dari dua bentuk, yaitu karya sastra berbentuk tulisan tangan dan karya sastra tulis yang berbentuk cetakan. Karya sastra yang berbentuk tulisan tangan (manuscript) sering disebut sebagai karya sastra Indonesia klasik atau lama atau tradisional. Adapun karya tulis yang berbentuk cetakan atau tulisan cetakan sering disebut sebagai karya sastra Indonesia modern (Baroroh-Baried dkk., 1994:55). Manuscript merupakan objek material penelitian filologi karena di dalamnya menyimpan berbagai ungkapan pikiran dan perasaan sebagai hasil budaya bangsa masa lampau (Baroroh-Baried dkk., 1994:55). Menurut Djamaris (2002:7), filologi adalah suatu ilmu yang objek penelitiannya adalah naskah-naskah lama dan meneliti latar belakang kebudayaan yang melatarbelakangi lahirnya suatu suatu naskah, seperti kepercayaan, agama, adat-istiadat, dan pandangan hidup. Adapun tugas pokok seorang filolog adalah presenting the text (penyajian teks) dan intepreting text (intepretasi teks).

Menurut Baroroh-Baried dkk. (1994:2-3), filologi dibagi menjadi dua, yaitu filologi tradisional dan modern. Filologi tradisional memandang variasi sebagai bentuk korup, tujuannya menemukan bentuk asli atau yang mendekati teks asli. Filologi modern memandang variasi teks secara positif, tujuannya untuk menemukan dan mengungkap makna yang muncul dalam berbagai variasi teks. Pada penelitian ini dipilih filologi modern karena peneliti ingin mengungkap isi dan makna yang terkandung dalam teks Kyai Prělambang pada naskah Kempalan Dongeng. Teks ini memuat cerita seorang ayah yang bernama Ki Prelambang yang mempunyai dua anak yang sangat berbeda satu sama lain, yang tua bernama Wasis adalah seorang yang pintar tapi mempunyai sifat yang kurang baik, yaitu serakah dan selalu ingin memiliki kepunyaan orang lain. Sedangkan adiknya yang bernama Jaka Bodho merupakan anak yang polos, bodoh tapi jujur dan berbudi pekerti yang baik. Keduanya disuruh ayahnya untuk bekerja di kota hingga akhirnya keduanya sukses dan dapat membanggakan ayahnya.

Teks ini mengandung makna yang mengandung nilai-nilai luhur yang dapat dijadikan teladan atau contoh untuk masyarakat di kehidupan sehari-harinya. Oleh sebab itu perlu dilakukan analisis lebih lanjut terhadap teks Kyai Prělambang. Analisis yang akan dilakukan yaitu dengan analisis semiotika. Semiotika adalah studi tentang tanda dan segala yang berhubungan dengannya: cara berfungsinya, hubungannya dengan tanda-tanda lain dengan pengirim dan penerimanya (Hastangka. dkk., 2018). Semiotik dipandang sebagai ilmu tentang tanda atau sebagai ilmu yang mempelajari sistem-sistem, aturan-aturan, dan konvensi yang memungkinkan tanda-tanda tersebut mempunyai arti. Menurut Riffaterre (1978:1) sebagai tanda, maka karya sastra dapat mengacu kepada sesuatu di luar karya sastra itu sendiri maupun di dalam dirinya. Atas dasar tersebut, maka Kyai Prělambang dapat dipandang sebagai semiotik atau sebagai tanda.

Penelitian ini akan membahas teks Kyai Prêlambang dalam naskah Kempalan Dongeng dengan menggunakan teori semiotik untuk mengetahui makna teks. Adapun teori yang dipakai dalam penelitian ini adalah teori semiotika. Semiotika dapat dibedakan ke dalam semiotik komunikasi, yaitu yang menekankan pada teori produksi tanda dan damiotik signifikasi yang menekankan pada pemahaman atau pemberian makna suatu tanda (Nurgiyantoro, 1994). Sebagai sistem tanda, karya sastra selalu mengekspresikan suatu hal secara tidak langsung (Riffaterre, 1978:1). Oleh karena itu bahasa yang digunakan pun berbeda dari bahasa pada umumnya karena karya sastra (puisi) memberi makna tersendiri bagi pembacanya.

Selain itu, karya sastra tidak bisa lepas dari pembaca. Oleh pembaca, karya sastra diterjemahkan oleh pikirannya atau dan dimaknai sesuai dengan pengetahuannya masing-masing. Dalam bukunya, Semiotic Of Poetry (1978), Riffaterre membahas langkah-langkah untuk menemukan makna suatu karya sastra (puisi) mulai dari pembacaan teks sampai kepada pemaknaan di luar teks. Untuk itu, Riffaterre mengungkapkan bahwa karya sastra merupakan dialektika antara teks dan konteks penciptaannya. Riffaterre juga mengungkapkan hal mengenai makna sebuah teks karya sastra melalui beberapa ketidaklangsungan makna dalam karya sastra 
(puisi) yakni displacing (pergantian makna), distorting (penyimpangan makna), dan creating (penciptaan makna) (Rifaterre, 1978:1-2).

Dengan ketidaklangsungan makna di atas, pembaca 'dipaksa' menggunakan kompetensi sastranya untuk memaknai bacaannya agar ia menemukan makna karya sastra yang ia baca. Untuk memaknai sebuah karya sastra, Riffaterre memberikan langkah-langkah dimulai dari pembacaan. Pembacaan teks oleh Riffaterre dibagi menjadi dua tahap yakni heuristik dan hermeneutik. Pembacaan heuristik merupakan pembacaan dengan menginterpretasikan teks sastra secara referensial lewat tanda-tanda linguistik (Riffaterre, 1978:5). Dengan kata lain, membaca berdasarkan struktur bahasa tahap pertama dengan melakukan interpretasi dalam tataran mimetik atau memaknai secara referensial. Faruk (2012:144) menjelaskan bahwa pembacaan heuristik dilakukan dengan menggunakan kode bahasa referensial yaitu yang mengandaikan bahwa tandatanda yang terdapat dalam teks puisi yang diteliti mengacu kepada satuan-satuan kenyataan yang terdapat dalam dunia empirik. Namun demikian, ada unsur-unsur bahasa yang menyimpang dari bahasa yang digunakan oleh karya sastra. Oleh karena itu, selanjutnya dilakukan pembacaan hermeneutik untuk menafsirkan unsur-unsur menyimpang atau ungrammatical, ketidaksesuaian antara satuan-satuan tanda kebahasaan yang ada di dalam teks dengan gambaran mengenai kenyataan yang diacunya (Faruk, 2012:148).

\section{METODE}

Metode penelitian yang digunakan dalam penelitian ini adalah metode analisis konten (content analysis). Analisis konten merupakan “... teknik penelitian untuk membuat inferensi-inferensi yang dapat ditiru (replicable) dan sahih data dengan memperhatikan konteksnya" (Bungin, 2012:231). Richard Bud, dalam bukunya Content Analysis ini communication research mengemukakan analisis isi merupakan teknik sistematis untuk menganalisis isi pesan dan mengolah pesan atau suatu alat untuk mengobservasi dan menganalisis dokumen, perilaku komunikasi yang terbuka dari komunikator yang dipilih (Suprayogo, 2001:71). Fraenkel dan Wallen (2008:472) berpendapat bahwa analisis konten merupakan “... a technique that enables researchers to study human behavior in an indirect way, through an analysis of their communications." Maka, analisis konten merupakan teknik untuk menganalisis makna dari komunikasi yang dilakukan oleh manusia. Komunikasi dipandang berisi simbol-simbol yang harus dimaknai kontennya baik berupa komunikasi lisan maupun tulisan. Pembacaan hermeneutik bisa juga disebut dengan pembacaan retroaktif dengan memberikan tafsiran sesuai dengan konvensi sastra sebagai sistem semiotik tingkat kedua. Pembacaan ini dilakukan dengan membaca teks dari awal hingga akhir, melakukan pengelihatan, dan perbandingan ulang ke belakang, menelusuri teks, dan mengenalinya, menempatkannya bersama-sama, bahnya pernyataan beruntun yang berbeda, yang awalnya diperhatikan sebagai tidak gramatikal, sesungguhnya ekuivalen, karena semua itu sebagai varian dari matriks struktural yang sama (Riffaterre, 1978:5-6; Faruk, 2012:145).

Selanjutnya dalam mencari makna sebuah teks menggunakan teori Riffaterre adalah dengan mencari matriks, model, dan varian. Matriks merupakan kata kunci yang memberikan makna pada sabuah karya sastra. Riffaterre mengandaikan karya sastra dengan sebuah donat yang ditengahnya memiliki ruang kosong. Ruang kosong tersebut merupakan pusat pemaknaan. Ia adalah inti makna. Ruang kosong sebagai pusat atau inti pemaknaan inilah yang disebut Riffaterre dengan matriks. Matriks tidak terdapat di dalam teks sehingga harus dieksplisitkan oleh pembaca. Matriks dapat berupa satu kata, frase, ataupun kalimat. Matriks belum merupakan sebuah tema dalam teks namun matriks mengarah kepada tema. Matriks diaktualisasikan dalam bentuk model. Model adalah bentuk nyata dari matriks yang juga dapat berupa satu kata, frase, atau kalimat yang terdapat di dalam teks. Model ini diaktualisasikan kembali menjadi varian berupa kalimat-kalimat sehingga varian merupakan bentuk penjabaran dari model (Riffaterre, 1978:12-20).

Langkah terakhir untuk memaknai sebuah teks karya sastra menurut Riffaterre adalah mencari hipogram. Hipogram adalah teks yang menjadi latar atau dasar penciptaan suatu teks lainnya. Hipogram biasanya merupakan satu kata, frase, kutipan, atau ungkapan klise yang 
merederensi pada frase/kata yang sudah ada sebelumnya (Riffaterre, 1978:23). Riffaterre membagi hipogram menjadi dua macam yaitu hipogram aktual dan hipogram potensial. Hipogram aktual adalah hipogram yang bersifat eksplisit atau nyata dan dapat diamati dari teks-teks karya sastra yang ada sebelumnya baik berupa kutipan, ungkapan, maupun isinya. Hipogram potensial merupakan hipogram yang dapat ditelusuri dalam bahasa yang bersifat hipotesis, seperti halnya yang terdapat pada matriks. Dengan demikian, jika hipogram dapat ditemukan, makna dan dasar penciptaan teks juga akan dapat ditemukan secara keseluruhan.

\section{HASIL DAN PEMBAHASAN}

Teks ini diawali dengan memunculkan tokoh Ayah (Ki Prelambang) dan kedua anaknya (Bagus Wasis dan Mas Bodho) sekaligus dengan sifat dan karakter dari kedua anak tersebut. Sifat dan karakter kedua anak Ki Prelambang ini menjadi sorotan utama pada bagian awal ini.

wontěn jalma ugi bawah Bahdani / Misilan wastaning dhusun / wasta Kyai Prělambang / darbe anak mung kěkalih sami jalu / Bagus Wasis ingkang tuwa / pintěr melian běsiwil ( $P$. $I: 1)$.

// Mas Bodho [h.128] ingkang taruna / busuk namung mantěp těměn taberi / bangět bodho culuk těrus / wau ta duk sěmana / Ki Prělambang langkung wagugen ing kalbu / dene suta kalihira / wus mangsa sami birahi (P. I : 2).

..ada orang yang masih termasuk di negara Bahdani, Misilan nama dusunnya. (Ia) bernama Kyai Prelambang, punya anak hanya dua laki-laki semua, Bagus Wasis yang sulung, pandai tapi nakal, selalu ingin memiliki kepunyaan orang lain.

Mas Bodho yang muda, polos tapi rajin dan bersungguh-sungguh, sangat bodoh dan sering bertanya terus.

Dari awal cerita tersebut menggambarkan bahwa terdapat dua macam karakter manusia yang saling bertentangan yakni baik dan buruk, terdapat karakter yang pintar dan yang bodoh, yang nakal, dan yang polos. Dengan kedua karakter yang bertentangan tersebut, pengarang lebih mudah untuk memberikan atau memasukkan ajaran-ajaran ke dalam teks. Hal tersebut kemudian direalisasikan dengan tindakan-tindakan kedua tokoh anak sesuai dengan karakter tersebut. Tindakan tokoh mengacu kepada pengertian pupuh pangkur di atas, terutama yang dilakukan oleh Bagus Wasis kepada adiknya, Bagus Bodho. Dari hal tersebutlah, ajaran-ajaran di dalam teks akan didapat.

Terdapat ketidakgramatikalan pada saat kedua anak tersebut tidak mengetahui jalan menuju kota besar, sehingga harus diantar ayah (Ki Prelambang) untuk sampai ke kota besar. Hal ini mengartikan bahwa hal-hal yang tidak pernah diketahui sebelumnya hanya dapat diketahui melalui seorang guru (Kyai) meskipun hal tersebut hanya berupa hal-hal yang kecil atau sepele. Dengan demikian, pengetahuan manusia tidak terlepas dari ajaran yang diberikan seseorang kepadanya. Ki Prelambang yang merupakan ayah dari kedua anak tersebut selalu memberi nasihat melalui perumpamaan-permupamaan dari tindakan kedua anaknya.

.../ Ki Prělambang nulya něbda / sun jarwani sira kalih.

// Iku pasěmoning jalma / yen manungsa ědak ladak ngědhingkring / iku busuk jatenipun / isine nora nana / lamun ana wong andhap asor ing laku / kaki poma den prayitna / yaiku pratandha isi (P. I : 9-10).

...Ki Prelambang kemudian berkata, "Kalian berdua kuberi tahu,itu seperti tingkah manusia, kalau manusia sewenang-wenang, itu sesungguhnya tidak baik, isinya tidak ada, tapi ketika orang rendah hati dalam berperilaku, kamu harus berhati-hati, hal tersebut bertanda ada isinya". 
// Eh thole aku wawarta / iya iku dadi pasmoning jalmi / kèlamun sira amuwus / ala mring samenira / sayěktine ngucap ala walěsipun / utang isin nyaur wirang / utang lara nyaur sakit.

// Utang pati nyaur pějah / yen wong iku dhěměn agawe běcik / iya winalěs rahayu / marang samaning jalma / [h.132] sabab iku sira dhewe ingkang muwus / ngumandhang sangking kadowan / nauri sěbarang angling (P. I :14-15).

"Eh anakku, aku beri tahu, itu menjadi perumpamaan manusia, kalau kamu berkata buruk terhadap sesama, sesungguhnya ucapan buruk itu akan menjadi balasan. Hutang malu dibayar malu, hutang sakit dibayar sakit.

Hutang nyawa dibayar mati. Kalau orang senang berbuat kebaikan, maka akan dibalas keselamatan juga dari sesama manusia. Maka dari itu kamu yang berbicara terdengar dari kejauhan menjawab sembarang kata".

Perumpamaan yang dikatakan oleh Ki Prelambang di atas, merupakan sebuah bentuk peringatan kepada kedua anaknya tentang perbuatan buruk yang dilakukan kepada seseorang akan dibalas sesuai dengan kadar perbuatannya. Begitu juga dengan perbuatan yang baik, akan mendapatkan balasan yang baik pula. Melalui perumpamaan tersebut Ki Prelambang juga mengingatkan kepada kedua anaknya untuk bersikap hati-hati terhadap segala perbuatan yang dilakukan. Melalui perumpamaan inilah kemudian cerita berlanjut sebagai bentuk realisasi di dalam teks.

Kepolosan dan kebodohan Mas Bodho yang ditampilkan dalam teks, seperti pada saat Mas Bodho tidak mengetahui padi yang masih kosong, dan gema suara yang dikiranya sebagai suara hantu, diartikan sebagai ketidaktahuan manusia sehingga harus mendapat pengetahuan dan pertolongan dari orang lain. Hal ini secara signifikan ditampilkan dalam teks, seperti ketika sesuatu menimpa Mas Bodho, ia segera mendapat pertolongan Tuhan melalui malaikat Jibril (yang berwujud seorang kakek) sehingga pada awalnya karakternya yang polos dan bodoh menjadi orang yang bijaksana.

Karakter Bagus Wasis dan Mas Bodho yang sangat bertentangan, timbul tindakan-tindakan yang sesuai dengan nasihat dan ajaran yang diberikan oleh Ki Prelambang kepada kedua anaknya. Dengan karakter Bagus Wasis yang selalu ingin memiliki kepunyaan orang lain dan sifat Mas Bodho yang polos, Bagus Wasis selalu memperdaya adiknya tersebut. Ketika Mas Bodho diperdaya-diusir, diamarahi, dipukul, difitnah- oleh kakaknya, ia selalu pergi ke dalam gua dan berkeluh-kesah di dalam gua tersebut. Gua dalam hal ini dapat diartikan sebagai tempat perenungan karena gua merupakan tempat yang sepi dan biasanya jauh dari keramaian dan berada di hutan ataupun kaki gunung. Keluh-kesah yang dilontarkan oleh Mas Bodho dianggap sebagai doa, sehingga ia mendapat pertolongan Tuhan melalui malaikat Jibril.

// Jabarail sarěng myarsa / ngrěrěs ing tyas wusana něbda aris / ah Bodho ingsun kang angsung / sandhang pangan / [h.135] mring sira lah nya iki kasang tampanana gupuh / yen sirarsa amamangan / sak karěpmu dentěkani (P. I : 25-26).

Malaikat Jibril ketika mendengar (ucapan Mas Bodho) sedih hatinya, akhirnya berkata lembut. "Bodho, aku yang akan memberi pakaian dan makanan kepadamu. Terimalah kantong ini segera. Jika kamu mau makan sesukamu akan tercukupi

oleh kantong itu, pukul halus (telapak tangan) kantong itu kalau kamu mau meminta sesuatu"

Dengan kehadiran malaikat Jibril pada saat Mas Bodho tertimpa kesusahan, merupakan sebuah pertanda pertolongan Tuhan atas permintaan atau doa yang diucapkan oleh Mas Bodho. Petolongan berupa kantong yang dapat mengeluarkan apapun permintaan, angsa yang juga dapat 
mengeluarkan apapun yang diminta, dan tongkat sakti merupakan bentuk bantuan dari Tuhan kepada hambanya. Hal ini juga menunjukkan bahwa manusia tidak bisa berbuat sesuatu tanpa pertolongan Tuhan.

Ketidakgramatikalan juga ditemukan ketika Raja Bahdani tengah menghadapi masalah yang tidak dapat dipecahkan oleh dirinya beserta orang-rang di dalam kerajaan. Ia mendapat mimpi yang menganggu ketentramannya yakni Ratu jin, Raja Godaha Dharma, yang ingin mengambil anak Raja, Dyah Jumilahin, dan bersiap untuk perang dengan Raja apabila ia tidak menyerahkan anaknya.

// Prabu Kusnun tan suka těmahan yuda / lan Raja Ngambar Dangin / Sri Kusnun kasoran / wusana Nata nébda / marang sagung ingkang nangkil / eh kawruhana / sakehe bocah mami.

// Ingsun iki saběn ratri ngimpi yuda / kělawan ratuning jin / Raja Godha Darma / Ngambar Dangin něgara / prakarane arsa nga[h.157]mbil / mring putraningwang / mring Dewi Jumilahin.

// Ing saiki ingkang dadi karsaningwang / sakehe wadya mami / sapa ingkang bisa / ngalahkěn impeningwang / sun paringi nini putri / lawan sunangkat / dadiya patih mami (P. II :36-38).

Prabu Kusnun tidak suka terjadi perang dengan Raja Ngambar Dangin. Sri Kusun kalah, akhirnya raja berkata kepada semua yang menghadap, "Hai ketahuilah semua anakku, saya ini setiap malam bermimpi perang melawan ratunya Jin, Raja Godha Darma, (dari) negara Ngambar Dangin. Permasalahnnya (dia) akan mengambil anakku, yaitu Dewi Jumilahin.

Sekarang yang menjadi keinginanku, segenap perajuritku, siapa yang bisa mengalahkan mimpiku, saya beri (seorang) putri perempuan dan saya angkat menjadi patihku".

Hal yang tidak gramatikal di sini adalah kekhawatiran raja terhadap mimpinya. Ia membuat solah-olah mimpi tersebut nyata. Hal ini diartikan bahwa kekhawatiran manusia yang berasal dari pikirannya dan akan mempengaruhinya pada dunia nyata. Oleh karena itu, raja membuat sayembara untuk mengusir Raja Jin dari dalam mimpinya dengan hadiah jabatan dan putrinya.

Makna dari nama tokoh pada teks teks Kyai Prêlambang dalam naskah Kempalan Dongeng ini yang juga merupakan sebuah perumpamaan atau kiasan. Nama Bodho (bodoh), diartikan sebagai tidak lekas mengerti; tidak mudah tahu atau tidak dapat (mengerjakan dsb); tidak memiliki pengetahuan, pendidikan, pengalaman (2015:203). Dalam kepolosan dan ketidaktahuan Mas Bodho di awal cerita, terdapat kelebihan-kelebihan yang dimilikinya berupa keberuntungan dengan mendapatkan pertolongan Gusti Allah melalui malaikat-sehingga ia berubah menjadi orang yang bijaksana, yang dikasihi Gusti Allah, dan dapat berbuat kebajikan pada sesama manusia. Dengan demikian, sebagai balasannya, akan mendapat kedudukan yang tinggi. Hal ini juga menunjukan bahwa dengan belajar, berusaha, dan berdoa, nasib yang buruk akan berubah menjadi baik.

Nama bukan menjadi persoalan melainkan perbuatan dan kabajikan yang dilakukan menjadi tolak ukur dalam pembelajaran kehidupan. Hal tersebut didukung dengan nama Wasis yang mempunyai arti pintar dan bisa (Poerwadarminta (1939:657), namun mempunyai sifat yang kurang baik, yaitu selalu mengambil hak adiknya yang bodoh dan mudah diperdaya. Karena perbuatannya itu dia mendapatkan balasan dari Tuhan. Hingga pada akhirnya dia bertaubat dan mengikuti apapun keinginan adiknya yang sebelunya selalu diperdaya. Karena kesadaraannya untuk berubah inilah, pada akhirnya ia juga mendapatkan kebahagiaan.

\section{Matriks, Model, dan Varian}


Setelah dilakukan pembacaan hermeneutik terhadap teks Kyai Prêlambang dalam naskah Kempalan Dongeng, maka langkah selanjutnya adalah mencari dan menentukan matriks, model, dan varian dari teks tersebut. Seperti yang telah dikemukakan pada landasan teori, matriks merupakan pusat pemaknaan. Matriks dalam teks Kyai Prêlambang dalam naskah Kempalan Dongeng adalah pendidikan dan pengajaran. Matriks tersebut ditransformasikan menjadi model perumpamaan yang berisi kebaikan, keburukan, usaha, dan imbalan.

Model keburukan ditunjukkan saat Bagus Wasis bertindak sewenang-wenang terhadap Mas Bodho, adiknya. Model kebaikan ditunjukkan saat Mas Bodho memberi kakaknya berupa kantong, angsa, dan tongkat. Kemudian, pada saat ia membantu kakaknya keluar dari penjara dan membantu Raja Bahdani untuk menghilangkan Raja Jin yang menganggu di dalam mimpinya. Kebaikan juga ditunjukkan Gusti Allah melalui malaikat Jibril untuk menolong Mas Bodho pada saat tertimpa kesusahan. Model imbalan ditunjukkan pada saat Mas Bodho dan Mas Carik berhasil mengalahkan Raja Jin dari mimpi Raja Bahdani, mereka mendapat imbalan jabatan dan seorang putri untuk Mas Bodho. Selain itu, Ki Prelambang, ayah Mas Bodho dan Bagus Wasis mendapatkan tanah dari kedua anaknya yang sudah berhasil sehingga dapat membangun rumah dan mesjid.

Berdasarkan model di atas, ditransformasikan lagi menjadi bentuk-bentuk varian. Varian merupakan aktualisasi dari matriks dan juga model. Dengan demikian, varian dari teks Kyai Prêlambang dalam naskah Kempalan Dongeng adalah sebagai berikut. Varian pertama adalah memberikan nasehat, ilmu, ataupun pertolongan terhadap orang-orang yang membutuhkan. Hal ini ditunjukkan oleh Ki Prelambang kepada kedua anaknya, baik sebelum mereka berangkat ke kota besar, maupun setelah mereka menjadi orang yang berhasil.

// Den jělimět sira kaki / těgěse dipunwaspada / barang [h. 173] pěngarahmu angger / dipun gěmět pamrihira / cakěping reh tan kewran / dipunměmèt ing karěpmu / aja nganti kěnyana lyan (P. IV : 11).

Hendaknya engkau seksama nak, artinya waspadailah apa yang akan kamu lakukan nak, kamu teliti (pikirkan) akibatnya, perihal segala tindakannmu tidak kesulitan, dipertimbangkan keinginanmu, jangan sampai disangka yang lain.

// Thole ingsun amuwuhi / thole esthinen wardaya / tělung prakara kathahe / aja sira kěmba-kěmba / sěbarang karěpira / aja bosěn sira kulup / marang ing reh kapěnédan ( $P$. IV : 17).

Anakku, aku menambahi. Anakku, camkan baik-baik dalam hati, tiga hal banyaknya. Jangan kamu setengah-setengah, apapun keinginanmu jangan bosan kamu ikut pada yang memberikan kehidupan.

Dipunpalamarta adil / ngadil [h.175] běněr kukuh panggah / jějěg ajěg tanpa menggok / marta marang pangapura / ngapureng kaluputan / luputing jalma sědarum / kang kěna dipunapura $(P . I V: 20)$.

Berbelas kasih dan adil, adil benar, kokoh, sentosa. Tetap kukuh tanpa menyimpang, sabar (dan selalu) memaafkan, memaafkan kesalahan, kesalahan semua orang yang dapat dimaafkan .

// Pala lire marang pěrdi / pinrědi barang kagunan / amrih kaslametaning wong / tanapi mring panggaweyan / dennya met upajiwa / yen kěsed dleya tan nurut / winulang kělawan peksa $(P . I V: 21)$. 
Manfaatnya maksudnya pada ajaranyang baik, ajaran yang baik (itu) harta milik kita (untuk) mendapatkan keselamatan orang juga untuk pekerjaan. Maka kamu carilah rejeki, kalau malas seenaknya sendiri (dan) tidak nurut, dinasehati dengan dipaksa.

Varian kedua adalah tindakan buruk dan keserakahan akan segera terbalaskan. Hal ini ditunjukkan melalui kesewenang-wenangan Bagus Wasis (Mas Carik) terhadap adiknya Jaka Bodho (Mas Bodho).

// Sangsaya sakwěnang-wěnang / mring Gus Bodho drěngkine saya dadi / tan eling sugihe $i k u$ / marga saking rinira / pikirira lan rabine sampun rujuk / kuwatir yen lawas-lawas / Mas Bodho yen wis rabi.

// Tamtu jaběl kasang banyak / saběn dina arine dencěcěnggring / sinrěrěng tinundhungtundhung / Mas Bodho tan tahan / den ilani pangane sakdinanipun / nuli lumajar mring wana / wangsul manjing guwa malih. (P. I : 50-51).

Lama-lama Gus Carik semakin sewenang-wenang terhadap Gus Bodho, kebenciannya semakin menjadi-jadi, tidak ingat kalau kekayaan itu dari adiknya. Dia dan istrinya berpikiran sama, kuatir kalau lama kelamaan Mas Bodho sudah menikah,

tentu akan meminta kantong dan angsa tersebut. Setiap hari adiknya disia-sia, dimarahmarahi dan selalu diusir, Mas Bodho tidak tahan, dia makan makanannya hari itu kemudian pergi ke hutan, kembali masuk gua lagi.

Hal ini dilakukan semata-mata untuk mendapat kekayaan dari apa yang didapat oleh adiknya berupa kantong, angsa, yang dapat mengeluarkan apa saja yang diinginkan. Oleh karena itu, Bagus Wasis dan istrinya menginginkan agar Mas Bodho pergi sehingga mereka mendapatkan kedua benda tersebut dan menggunakannya untuk kepentingan mereka sendiri. Tindakan buruk yang dilakukan Bagus Wasis terhadap adiknya tersebut, mendapatkan balasan. Balasan tersebut didapat melalui tongkat sakti milik Mas Bodho pemberian malaikat Jibril.

// Mas Bodho eca nendra neng pěndhapa / pěnthunge denkěloni / sěksana garonjal / pěnthung mlayu priyangga / nututi tiyang kěkalih / kang arsa minggat / kěca[h.151]ndhak den pěnthungi.

// Sirahira Mas Carik kadi pěcaha / nanging tan prapteng pati / kang wadon ya muncrat / piněnthung wantu-wantu / sěksana anggrajag gětih / samya sěsambat / dhuh bojo ari mami.

// Sun wus tobat tan nědya anginggatěna / kasang banyakmu iki / wis pěnthung lungaa / měngko ingsun kěpanggya / mring Si Bodho kadang mami / pěnthung sěmana / Mas Carik denagagi.

// nuli mlayu wong roro marang pěndhapa / pěnthung tansah tut wuri / wus prapteng gonira / Ki Bodho gennya nendra / kagyat ingkang raka prapti / sarwi karuna / wis tobat aku yayi.

// ěnya iki kasangmu kélawan banyak / tan sida ingsun ambil / nanging pěnthungira [h.152] lah cěkělěn ta ika / ingsun arsa mulih guling / pěnthung wus niba / gumlinting aneng siti. (P. II : 12-16).

Mas Bodho tidur di pendapa, tongkatnya dipeluk, seketika bergerak (dengan) tiba-tiba tongkat berlari sendiri mengejar dua orang tersebut yang mau pergi, tertangkap (dan) dipukuli.

Kepala Mas Carik seperti pecah, tetapi belum mati, yang perempuan juga muncrat (darahnya), dipukul berkali-kali hingga bersimbah darah, sambil memelas, "Duh suamiku, 
aku sudah taubat tidak akan membewa pergi kantong (dan) angsamu ini, sudahlah tongkat pergilah, nanti aku bertemu dengan Si Bodho saudara kami”. Tongkat ketika itu (berhenti). Mas Carik dilepaskan,

lalu dua orang berlari menuju pendapa, tongkatnya selalu mengikuti dibelakang, sudah sampai ditempat Ki Mas Bodho tidur. (Ki Bodho) kaget atas kedatangan kakaknya. Sambil menangis, "Sudah taubat aku adekku,

Ini kantongmu dan angsa, tidak jadi aku ambil, tapi tongkatmu ini peganglah, aku akan pulang tidur". Tongkat sudah jatuh tergeletak di tanah.

Setelah dipukuli oleh tongkat sakti tersebut Bagus Wasis dan istrinya bertaubat dan mengembalikan benda-benda milik Mas Bodho dan juga memberikan rumah mereka kepada Mas Bodho. Dengan demikian, akibat keserakahan dan sikap buruk Bagus Wasis terhadap adiknya, ia mendapatkan balasan dengan kehilangan semua harta bendanya.

Varian ketiga adalah pertolongan gusti Allah selalu datang kepada orang-orang yang 'kesusahan' dan berdoa. Hal ini ditunjukkan ketika Mas Bodho diusir oleh kakaknya, Bagus Wasis dan ia lari ke dalam gua. Ia berkeluh kesah (doa) sehingga pertolongan gusti Allah melalui malaikat Jibril datang kepada Mas Bodho.

// Aneng wisma Ki Jaka manggung mangunkung / dahad dennya mati ragi / yen dalu tansah pitěkur / lami ngantya sapta latri / Mas Bodho mogok-mogok.

// Tandya wontěn parmaning Yyang Mahaluhur / Jabarail anědhaki / angsung salam sarwi muwus / eh ta Bodho sira uwis / tinrima dening Yyang Manon.

// Olehira něnuwun marang Yyang Agung / saksědyanta denturuti / ywa sira manggung wulangun / Gusti ingkang Mahasuci / tan samar sakkrěntěging wong. (P. III : 5-7).

Di rumah Ki Jaka selalu bersedih, dia sangat berprihatin. Kalau malam selalu duduk terdiam lama, sampai tujuh malam Mas Bodho diam.

Kemudian ada belas kasih Tuhan Maha Agung, malaikat Jibril mendekati memberi salam sambil berkata, "Eh Bodho, kamu sudah diterima oleh Gusti Allah.

Permintaanmu kepada Tuhan Maha Agung, apapun permintaanmu dituruti.

Varian keempat adalah berusaha dalam mendapatkan sesuatu. Hal ini ditunjukkan Bagus Wasis sehingga ia dapat membangun rumah dalam waktu singkat. Selain, itu usaha Mas Bodho untuk medapatkan putri raja dilakukan dengan terlebih dahulu mengusir raja jin.Varian kelima yaitu usaha perlawanan terhadap Belanda yang digambarkan ketika pertarungan Bagus Bodho dan Bagus Wasis melawan raja Jin yang selalu mengganggu Raja Bahdani dan mengancam akan membunuh Raja. Varian ke enam adalah balasan terhadap perbuatan yang baik. Hal ini ditunjukkan oleh Raja kepada Mas Bodho dan Bagus Wasis ketika mereka mengalahkan raja jin.

// Angandika wau Sang Narendra Kusnun / eh Bodho sira sakiki dadiya pěpatih ingsun / jěněnga Raden Dipati / wicaksana iku manggon.

// Lawan iya sun trimani putraningsun / Nini Dewi Jumilahin / Si Wasis iku sun junjung / dadi bupa[h.168]ti pulisi / bumi seni bawahing ngong. P. III : 44-45).

Diceritakan Sang Raja Kusnun berkata, "Eh Bodho, kamu sekarang jadilah patihku, bernamalah Raden Dipati Wicaksana itu tepatnya.

Dan engkau aku beri hadiah putriku, putri Dewi Jumilahin. Si Wasis aku angkat menjadi menteri keamanan wilayah kekuasaanku.

Varian ketujuh adalah berbakti dan membalas jasa kepada orang tua. Hal ini ditunjukkan oleh Bagus Wasis dan Mas Bodho kepada ayahnya. 
// Matur nuwun putra kalih / mangestu sabdeng sudarma / Dyan Dipati matur alon / Kyai yen Parěng panduka / kula atur punjungan / warni sabin satus bau / kang cělak cělak Misilan.

// Kinarya sangu mumuji / dongakkěn wilujěng amba / sampun wontěn sangsarane / Raden Tuměnggung pyayama / [h.176] kyai inggih kawula / munjung sabin sekét bau / angsala brěkah Panduka.

// Sudarma mangsuli aris / kulup karo sun tarima / sangking běktimu maringong / ya ingsun tampani padha / punjunganmu maring wang / sun gawene dana kulup / marang jalma sudra papa. (P. IV : 23-25).

Kedua anaknya berterimakasih (dan akan) melaksanakan nasihat ayahnya. Raden Adipati berkata pelan, "Kyai, kalau diijinkan paduka, saya beri hadiah berupa sawah seratus bau (ukuran luas, $\pm 7096.5 \mathrm{~m}^{2}$ ) yang dekat dengan Misilan.

Untuk bekal berdoa, mendoakan keselamatan saya, jangan ada kesusahannya". Raden Tumenggung berkata, "Kyai, iya saya memberi sawah lima puluh bau (agar) mendapatkan berkah Paduka".

Ayahnya menjawab pelan, "Anakku, keduanya kuterima, karena baktimu kepadaku, ya aku terima semua hadiah kalian kepadaku. Aku pergunakan pemberian anakku pada orang miskin".

Setelah kedua anak Ki prelambang berhasil, mereka membalas jasa ayahnya dengan memberi beberapa bidang tanah dan sawah sebagai rasa terimakasih, yang kemudian dijadikan rumah dan mesjid. Hal ini juga merupakan imbalan kepada Ki Prelambang atas segala nasehat, didikan, dan ajarannya terhadapa kedua anaknya tersebut.

\section{Hipogram}

Langkah terakhir untuk memberi pemaknaan terhadap teks Kyai Prêlambang dalam Naskah Kempalan Dongeng adalah mencari hipogramnya. Hipogram merupakan teks lain yang menjadi dasar penciptaan ataupun latar belakang sebuah teks (Riffaterre, 1978:2). Hal tersebut dapat berupa peristiwa sejarah, masyarakat dan unsur teks lain. Terdapat dua macam hipogram yaitu hipogram potensial dan hipogram aktual. Hipogram potensial merupakan hipogram yang implisit di dalam teks, sama halnya dengan matriks, yang berupa kata, frase, atau kalimat sederhana. Hipogram aktual adalah hipogram yang eksplisit berupa teks nyata, dapat berupa kata, kalimat, atau seluruh teks yang lain (Rifaterre, 1978:23).

\section{Hipogram Potensial}

Sama halnya dengan matrik, hipogram potensial tidak tereksplisitkan di dalam teks. Namun, pembaca dapat mengambil makna kebahasaan yang bersifat hipotesis. Teks Kyai Prêlambang dalam Naskah Kempalan Dongeng merupakan teks yang digubah pada abad ke-19 tepatnya pada 1875 (Saktimulya, 2005:167). Dilihat dari struktur cerita teksnya, teks naskah Kyai Prêlambang dalam naskah Kempalan Dongeng ini tidak terlepas dari pengaruh budaya. Teeuw (1983:61) menyatakan bahwa karya sastra tidak dapat dilepaskan dari fakta sejarah dan sosial budayanya.

Menurut Zoetmulder (1974:ix) pengaruh budaya asing tidak dapat dilepaskan dengan kehidupan sastra Jawa. Pengaruh tersebut telah berlangsung sejak lama, sejak munculnya teks sastra keagamaan berbentuk prosa dalam sastra parwa sampai dengan sastra Jawa yang bersifat kerakyatan pada masa sastra Jawa modern kini. Di antara pengaruh budaya luar itu, pengaruh budaya asing yang cukup menonjol dalam teks ini adalah budaya islam.

Menurut Fanani (2005:17-25), karya sastra yang muncul pada saat pengaruh islam masuk ke dalam sastra Jawa, terjadi perubahan dari karya kakawin menjadi sastra tembang, baik tembang macapat, maupun tembang gede. Lebih lanjut, sastra jawa pada abad ke-19 tergolong ke dalam 
sastra Jawa Pramodern yang kebanyakan berbentuk prosa, yakni berupa kisah perjalanan, otobiografi, cerita didaktik, dan dongeng, serta cerita anak-anak. Oleh karena itu, teks ini tergolong kedalam jenis karya sastra Jawa di atas yang berbentuk dongeng, terdapat nilai didaktik, dan terdapat pengaruh nilai-nilai budaya islam.

Lebih lanjut, seperti yang dikemukakan oleh Kartodirdjo (dalam Riyadi, 2002:229-233) bahwa sejak Belanda mempunya pengaruh politik di Jawa, kekuasaan politik kerajaan Jawa berangsur-angsur mundur. Pengaruh Belanda semakin besar sejak disetujuinya perjanjian Gianti, tahun 1755, yang membagi kerajaan mataram menjadi dua yaitu Surakarta dan Yogyakarta. Ketika naskah ini digubah tahun 1875, saat itu Kadipaten Pakualaman yang berada di bawah kekuasaan Kraton Yogyakarta dipimpin oleh Paku Alam IV. Pada saat itu masa pemerintahannya ditandai dengan kemunduran Kadipaten Pakualaman. Banyak dari kebijakan Surya Sasraningrat (Paku Alam IV) menimbulkan ketidakpuasan. Selain itu ia tidak begitu mahir dalam hal kesusastraan dan kebudayaan. Di keluarga besar Paku Alam pun terjadi beberapa perubahan yang cenderung kurang baik akibat sering bergaul dengan orang-orang Belanda. Kemewahan dan foyafoya menjadi penyebab kehancuran beberapa anggota keluarga Paku Alam.

Aspek lain yang juga andil mendukung keberlangsungan gaya hidup mewah para bangsawan Jawa waktu itu adalah dibangunnya transportasi modern terutama kereta api. Proyek pembangunan jalur kereta api pertama di Hindia Belanda diterapkan pada jalur yang menghubungkan Semarang dengan Vorstenlanden. Konsesi pembangunan tersebut diberikan oleh pemerintah kepada pihak swasta, yakni NISM (Nederlandsch-Indische SpoorwegMaatschappij) pada tahun 1862 dan selesai pada tahun 1873 (Wardojo, 2012:75).

Oleh karena itu, norma-norma dan nilai tradisional tergeser sehingga mendorong paja pujangga istana sebagai intelektual kerajaan berusaha mengatasi krisis itu dengan menulis seratserat yang berisi pendidikan moral dengan tujuan melestarikan norma-norma dan nilai-nilai yang diwariskan oleh nenek moyang atau setidaknya menjaga agar perubahan norma dan nilai tersebut tidak menurunkan harkat dan martabat istana. Oleh karena itu, karya-karya atau naskah-naskah yang dihasilkan, terutama pada kesultanan Yogyakarta, mengandung nilai religius, didaktis, dan kepahlawanan. Hal tersebut juga tergambar pada teks Kyai Prêlambang ini.

Menurut Kamus Besar Bahasa Indonesia (2015:694) Kiai adalah sebutan bagi alim ulama (cerdik pandai dalam agama Islam); sebutan bagi guru ilmu gaib. Sedangkan 'Prelambang' (perlambang) diartikan sebagai isyarat atau tanda-tanda; sesuatu yang gaib atau yang harus dihormati. Oleh karena itu, teks ini berisi mengenai ajaran-ajaran, nasehat, dan meliputi hal-hal gaib seperti malaikat (Jibril), serta benda-benda 'sakti' seperti sastra Jawa pada umumnya. Lebih lanjut, karakter Ki Prelambang sendiri merupakan aktualisasi dari Kiai yang selalu memberikan nasehat dan ajaran kepada manusia lainnya (kedua anaknya) juga kepada santri (yang tergambar di akhir cerita).

Selain menggambarkan ajaran-ajaran dan nilai-nilai keislaman yang terdapat di dalam teks Kyai Prêlambang ini, juga terselip unsur-unsur kekuasaan di dalamnya. Sejak terpecahnya kerajaan Mataram menjadi Yogyakarta dan Surakarta, kekuasaan Belanda menjadi semakin kuat diiringi dengan berkurangnya kekuasaan raja. Pergantian raja harus mendapat izin dari pihak Belanda. Para residen yang bertugas di keraton dan sebelumnya hanya berperan sebagai semacam perwakilan Belanda, kini dalam upacara keraton mendapat kedudukan yang sama dengan raja. Sebelumnya mereka hanya mencampuri pengawasan atas peraturan negara tentang candu, pengawasan atas penyewaan dan cukai pasar, dan perlindungan bagi kepentingan penyewa tanah bangsa Eropa, sejak 1830 Belanda juga mencampuri pengadilan (Ras, 1988:275).

Terdapat juga kekuasaan Raja sebagai susuhunan dalam teks ini. Meskipun berada di bawah pengaruh Belanda, raja tetap menjadi penguasa atas rakyatnya sehingga raja juga bebas memerintah rakyat selain bekerja sama dengan pihak Belanda. Kekuasaan raja pada teks ini ditunjukkan melalui tindakannya memenjarakan Bagus Wasis dan memerintahkan raja jin yang 
kalah untuk membangun kereta beserta rel. Selain itu, ajaran yang dapat dimbil dari sikap sang Raja adalah menepati janjinya atas sayembara yang telah dibuat.

Dari kekuasaan antara raja dan pihak Belanda di atas, sesuai dengan konteks penciptaan teks pada saat itu, dalam buku yang berjudul Sejarah Kebangkitan Nasional Daerah Istimewa Yogyakarta (1977/1978), menyatakan bahwa makin luasnya pengaruh kehidupan Barat dalam lingkungan kehidupan tradisonal, timbul perasaan khawatir di kalangan penguasa bumiputera bahwa pengaruh kehidupan Barat tersebut dapat merusak nilai-nilai kehidupan tradisional. Oleh karena itu para pemimpin agama menentang kehidupan Barat itu karena bertentangan dengan ajaran Islam meskipun kebudayaan Indonesia dapat tetap bertahan dan semakin kaya (dalam buku Sejarah Kebangkitan Nasional Daerah Istimewa Yogyakarta. 1977/1978:25). Dengan demikian, teks ini juga sebagai lambang perlawanan 'halus' terhadap Belanda (di dalam teks merupakan Raja Jin) yang juga merupakan sebagai 'pembangun' teknologi (kereta api) di Indonesia.

Selanjutnya adalah kekuasan Tuhan yang dapat mengabulkan seluruh permintaan hambaNya yang berdoa. Dengan memohon doa kepada Gusti Allah, segala usaha yang dilakukan manusia akan mendapat manfaat dan terlaksana. Pertolongan yang diberikan Tuhan tidak hanya sekali melainkan berkali-kali, karena Tuhan memiki sifat Maha Pengasih dan Maha Pemurah. Tanpa adanya izin dari Tuhan, segala niat tidak akan dapat terlaksana. Hal ini jelas tergambar pada teks Kyai Prêlambang melalui hadirnya malaikat Jibril yang memberi pertolongan kepada tokoh Bagus Bodho. Hal ini merupakan nilai-nilai islam yang disematkan dalam teks ini untuk mengajarkan kebesaran Tuhan terhadap hamba-Nya.

\section{Hipogram Aktual}

Hipogram aktual merupakan hipogram yang bersifat eksplisit dan berupa teks nyata. Hipogram ini menjadi latar penciptaan teks baru atau yang ditransformasikan dari teks lama menjadi teks baru. Hipogram aktual dapat diamati dalam teks-teks sastra sebelumnya baik berupa kutipan maupun unsur-unsur yang terdapat dalam teks lain. Hipogram aktual dari teks Kyai Prêlambang terdapat dalam teks-teks naskah sebelumnya yang masih dalam satu kempalan dongeng yang sama, Kisah Raden Mukjijat, Istrijat, dan Keramat. Selain ditransformasikan dari naskah tersebut, ajaran keislaman dan ilmu yang terkandung dalam teks Kyai Prêlambang juga ditransformasikan dari Kitab Sastra Gendhing karya Sultan Agung yang juga mengutip dari kitab Futuhat al-Makiyyah karya Ibnu Arabi; tentang keselarasan bertasawuf dan bersyariat (Abimanyu, 2014:483-485). Adapaun kutipan dari kitab Sastra Gendhing tersebut adalah sebagai berikut.

"Dan janganlah bertengkar pendapat, itu pantangan dalam dunia ilmu, lebih baik diam dulu, tetapi sambil giatlah dalam belajar kepada ulama serta para sarjana yang ahli” (Sastra Gendhing V/16)

"Meskipun engkau telah mengerti, tak ada celanya meminta fatwa para ulama, justru akan lebih utama, bila terdapat kesepakatan, 3 atau 4 orang alim" (Sastra Gendhing V/17)

"Karena itulah, hasil dari ilmu yang terikat erat dengan syariat membawa kesejahteraan mahkluk, maka jadilah manusia yang mendapatkan petunjuk menuju keutamaan, keutamaan dalam pemujaan kepada Allah" (Sastra Gendhing V/9).

Kutipan-kutipan di atas ditransformasikan menjadi nilai ajaran dalam teks Kyai Prêlambang. Dengan demikian, makna dari teks Kyai Prêlambang adalah ajaran-ajaran yang terkandung dalam agama Islam berupa kebaikan dan keburukan serta balasannya terhadap manusia sebagai hamba Tuhan, serta berusaha untuk mendapatkan dan menjaga apa yang telah dimiliki dengan berbuat kebajikan sesama manusia karena hal itu semua berasal dari Allah semata.

\section{SIMPULAN}


Nama tokoh pada teks teks Kyai Prêlambang merupakan sebuah perumpamaan atau kiasan. Nama Bodho (bodoh), diartikan sebagai tidak mudah tahu atau tidak memiliki pengetahuan (pendidikan, pengalaman). Dalam kepolosan dan ketidaktahuan Bagus Bodho, terdapat kelebihan-kelebihan yang dimilikinya berupa keberuntungan. Bagus Bodho menunjukan bahwa dengan belajar, berusaha, dan berdoa, nasib yang buruk akan berubah menjadi baik. Sedangkan nama Wasis yang mempunyai arti pintar dan bisa, namun mempunyai sifat yang kurang baik, yaitu selalu mengambil hak adiknya yang bodoh dan mudah diperdaya. Karena perbuatannya itu dia mendapatkan balasan dari Tuhan. Hingga pada akhirnya dia bertaubat dan mengikuti apapun keinginan adiknya yang sebelunya selalu diperdaya. Karena kesadaraannya untuk berubah inilah, pada akhirnya ia juga mendapatkan kebahagiaan. Dengan demikian, jelas bahwa teks ini merupakan ajaran-ajaran-yang terdapat dalam agama Islam yang diberikan seorang Kyai kepada muridnya untuk mengamalkan segala kebaikan dan selalu berusaha. Teks ini juga mengajarkan bahwa manusia sebagai hamba Tuhan akan mendapatkan imbalan dari setiap perbuatannya.

Setelah melakukan pembacaan hermeneutik kemudian pencarian matriks dalam teks Kyai Prêlambang. Hasilnya, matriksnya adalah pendidikan dan pengajaran. Matriks tersebut ditransformasikan menjadi model perumpamaan yang berisi kebaikan, keburukan, usaha, dan imbalan atau balasan. Model keburukan ditunjukkan saat Bagus Wasis bertindak sewenangwenang terhadap Bagus Bodho, adiknya. Model kebaikan ditunjukkan saat Mas Bodho memberi kakaknya berupa kantong, angsa, dan tongkat. Kemudian, ia membantu kakaknya keluar dari penjara dan membantu Raja Bahdani untuk menghilangkan Raja Jin yang menganggu di dalam mimpinya. Model imbalan ditunjukkan pada saat Bagus Bodho dan kakaknya mendapat imbalan jabatan dari Raja juga seorang putri untuk Bagus Bodho.

Berdasarkan model, ditransformasikan lagi menjadi bentuk-bentuk varian. Varian dari teks Kyai Prêlambang adalah tindakan buruk, pertolongan Gusti Allah, balasan tindakan buruk, pertolongan manusia, usaha perlawanan, perbuatan baik, balasan perbuatan baik, dan bakti kepada orang tua. Langkah terakhir adalah mencari hipogram. Terdapat dua macam hipogram yaitu hipogram potensial dan hipogram aktual. Berdasar pencarian hipogram potensial, pertama teks Kyai Prelambang berhubungan dengan kondisi sosial abad 18. Kedua, berhubungan dengan Islam: kekuasaan dari Allah dan ajaran dari kyai. Ketiga, berhubungan dengan kekuasaan raja di Yogyakarta dan Belanda. Hipogram aktual yang pertama yaitu naskah sebelum teks Kyai Prelambang yang masih dalam satu naskah Kempalan Dongeng: Kisah Raden Mukjijat, Istrijat, dan Keramat. Kedua, Sastra Gending karya Sultan Agung. Hasil pembacaan dan pencarian diatas dapat dibuat menjadi sebuah bagan analisis dibawah ini.

\section{DAFTAR PUSTAKA}

Baroroh-Baried, dkk. 1994. Pengantar Teori Filologi. Yogyakarta: Badan Penelitian dan Publikasi Fakultas.

Bugin, Burhan. (2012). Penelitian Kualitatif. Jakarta: Kencana Prenada Grafika.

Depdikbud. 1977/1978. Sejarah Kebangkitan Nasional Daerah Istimewa Yogyakarta. Jakarta: Departemen Pendidikan dan Kebudayaan Pusat Penelitian Sejarah Dan Budaya Proyek Penelitian Dan Pencatatan Kebudayaan Daerah.

Djamaris, Edwar. 2002. Metode Penelitian Filologi. Jakarta: CV Manasco.

Fanani, Muhammad. 1995. Hikayat Nur Muhammad. Jakarta: Pusat Pembinaan dan Pengembangan Bahasa, Departemen Pendidikan dan Kebudayaan.

Faruk. 2012. Metode Penelitian Sastra. Yogyakarta: Pustaka Pelajar.

Fraenkel, Jack. R., and Norman E. Wallen. 2012. How to Design and Evaluate Research in Education 8th Edition. Boston: McGraw-Hill Higher Education. 
Hastangka, Kaelan, Armaindy Armawi. 2018. Analisis Semiotika Pierce dalam Penggunaan Istilah Empat Pilar Berbangsa dan Bernegara MPR RI. Jurnal Litera, volume 17, nomor 3, halaman 349-366.

Kaelan, M.S. 2005. Metode Penelitian Kualitatif Bidang Filsafat Paradigma Bagi Pengembangan Penelitian Interdisipliner Bidang Filsafat, Budaya, Sosial, Semiotik, Sastra, Hukum dan Seni. Yogyakarta: Paradigma.

Nurgiyantoro, Burhan. 1994. Teori Semiotik dalam Kajian Kesastraan. Cakrawala Pendidikan, nomor 1, tahun XIII, halaman 51-66.

Padmosoekotjo, S. 1960. Ngréngréngan Kasusastran Djawa. Djilid I. Tjap-tjapan kaping papat. Jogjakarta: Hien Hoo Sing.

Poerwadarminta, W. J. S. 1939. Baoesastra Djawa. Groningen, Batavia: J. B. Wolters'Uitgevers Maatscappij.

Pradopo, Rachmat Djoko. 1990. Pengkajian Puisi. Yogyakarta: Gadjah Mada University Press.

Saktimulya, Sri Ratna. 2005a. Katalog Naskah-naskah Perpustakaan Pura Pakualaman. Jakarta: Yayasan Obor Indonesia-The Toyota Foundation.

Suprayogo, Imam. 2001. Metodologi Penelitian Sosial Agama. Bandung : PT. Remaja Rosdakarya.

W. W. Wardojo. 2012. "Jalur Kereta Api Semarang-Surakarta dan Pengaruh Sosial Ekonomi di Karesidenan Surakarta 1864-1930". Tesis Tidak Diterbitkan, Yogyakarta: UGM.

Zoetmulder. J.P. 1985. Kalangwan Sastra Jawa Kuno Selayang Pandang. Jakarta: Djembatan. 